\title{
A Defence of the Control Principle
}

\section{Martin Sand ${ }^{1}$}

Received: 30 October 2019 /Revised: 30 October 2019 / Accepted: 30 June 2020 /

Published online: 14 July 2020

(C) The Author(s) 2020

\begin{abstract}
The nexus of the moral luck debate is the control principle, which says that people are responsible only for things within their control. In this paper, I will first argue that the control principle should be restrained to blameworthiness, because responsibility is too wide a concept to square with control. Many deniers of moral luck appeal to the intuitiveness of the control principle. Defenders of moral luck do not share this intuition and demand a stronger defence of the control principle. I will establish a defence of the control principle based on the value of simplicity for selecting a theory of blameworthiness. A simpler theory of blameworthiness is more likely to be true, and not being falsely judged blameworthy is desirable. I will conclude that simplicity advices the acceptance of the control principle over other theories of blameworthiness that embrace factors beyond control.
\end{abstract}

Keywords Moral luck $\cdot$ Blameworthiness $\cdot$ Control principle $\cdot$ Simplicity $\cdot$ Blame

\section{Introduction}

Many deniers of moral luck believe that some version of the control principle (CP) is true. These philosophers suggest that intuition strongly advices this. Michael Zimmerman writes in recent papers that "the fundamental intuition that we cannot escape culpability through luck" is strong (Zimmerman 2015, p. 149), and that accepting moral luck "is not consistent with the intuition underlying" the control principle (Zimmerman 2019, p. 222). Prominently, David Enoch and Andrei Marmor argue that the control principle has "enough intuitive support and philosophical credentials that one would need very strong reasons to discard it." (Enoch and Marmor 2007, p. 407) $)^{1}$ Others joined such and similar pleas: Brynmor Browne writes that "we

\footnotetext{
${ }^{1}$ Recently, David Enoch proposes a different strategy against moral luck that does not rely on intuitions (Enoch 2019, 260 f.).
}

Martin Sand

m.sand@ tudelft.nl

1 Department of Values, Technology and Innovation, Faculty of Technology, Policy and Management, TU Delft, Jaffalaan 5, 2628 BX Delft, The Netherlands 
have a deeply rooted intuition which seems to tell us that the condition of control [...] is a requirement of moral agency," (Browne 1992, p. 348) and Andrew C. Khoury recently noted that "I myself (as well as many others) find it intuitive that resultant moral luck does not exist." (Khoury 2018, p. 1369).

However, it is clear that intuitions can mislead and have often misled philosophers. At least, one will have to admit that objections from defenders of moral luck will hit a more vulnerable target, if the control principle is supported by intuitions only. Nathan Hanna notes that - aside from intuition - the only argument brought forward in favour of CP is fairness, which he repudiates (Hanna 2014, p. 683). Also, Robert Hartman rejects fairness and states that deniers of moral luck "rely heavily on a principle-level intuition that desert of praise and blame is luck-free." Therefore, he finds it "worth considering whether CCP [Comparative Control Principle] has anything to recommend it beyond intuition." (Hartman 2016, p. 2849) This is a reasonable request. If Hartman's and Hanna's arguments against fairness and other objections against the luck-free account of responsibility are substantial, and the control principle bears solely on intuition, defenders of moral luck are in a better position. Thus, deniers of moral luck have to prospect for a more substantial defence of CP beyond its intuitive appeal. In this pursuit, I will provide an argument in favour of CP based on its simplicity in Section 3. Before, I will argue for a refinement of the standard formulation of $\mathrm{CP}$ in the next section to arrive at a more defensible formulation.

\section{Control and Blameworthiness}

In this section, I will first suggest to constrain CP to blameworthiness. Thomas Nagel conceived the moral luck problem originally as a paradox of ordinary morality. He introduces the paradox through a number of examples that supposedly show that people are responsible for things beyond their control, such as the consequences of their actions and the circumstances within which they act (Nagel 1991). It is the lack of control aspect of luck that gives rise to the controversy about luck's moral implications (Anderson 2019). When a drunken driver overruns a child on the street, he is allegedly more responsible than his lucky counterpart, who drives equally drunk but doesn't overrun a child. Whether a child appears on the street is beyond their control. Nagel writes that the assumption that the unlucky driver is more responsible than the lucky one, conflicts with our intuition "that people cannot be morally assessed for what is not their fault, or for what is due to factors beyond their control." (pp. 24-25) This formulation is instructive and underlies Dana Nelkin's standard formulation of the control principle, which says:

$\mathrm{CP}_{\mathrm{S}}$ : "We are morally assessable only to the extent that what we are assessed for depends on factors under our control." (Nelkin 2013)

Nagel concludes his discussion of moral luck claiming that it is paradoxical that a person "is not morally responsible for what he is and is not responsible for." (1991, p. 34) Before I defend the control principle for its simplicity in the next section, I will argue for a revision of $\mathrm{CP}_{\mathrm{S}}$. The control principle should contain blameworthiness instead of responsibility or moral assessment.

Both Nagel's formulation, which contains the term "responsibility" and suggests that he identifies moral assessment with responsibility, as much as $\mathrm{CP}_{\mathrm{S}}$ as formulated 
by Dana Nelkin, which centers around the term "moral assessment" instead of "responsibility", are misleading. The concepts "moral assessment" and "responsibility" are too wide to square with control.

Consider responsibility: In ordinary language, aside from the typical retrospective notion of responsibility (Fischer and Tognazzini 2011), responsibility also refers to what Michael Zimmerman calls deontic or prospective responsibility (Zimmerman 2006, 2015 , 2019). Deontic responsibility means having to ensure that certain states of affairs or events occur. This understanding of prospective responsibility largely resembles our understanding of moral obligation, but it is not quite congruent: Responsibilities that are related to roles, such as being a parent or a CEO, are forward-looking, too. But they are underdetermined regarding the kind of obligations they entail. Most importantly, whether someone is subjected to such prospective responsibility can be beyond control: If one accidently passes by a pond, in which a child is drowning, the person is responsible for saving it (Enoch 2019). In this manner, plain luck affects what is morally required from agents. The incurrence of such responsibility beyond control has no implications for blameworthiness. What might have an impact on blameworthiness is whether one fulfils an obligation incurred by chance (I say "might have", because there can be factors that excuse missing out on fulfilling such obligations). Also, "moral assessment" reaches beyond control as it comprises the assessment of the emotional responses to luck, for instance, in terms of agent-regret or remorse. Expectations regarding someone's emotional responses to an evil are often independent from the question of control. Whether family members of yours commit an evil, is not always within your control. But, if it happens, we expect you to be more emotionally affected than other people, not in terms of guilt, which is related to blameworthiness, but in terms of "sadness and pain and the accompanied wish that things had been otherwise." (Wolf 2001, p. 13) This is widely acknowledged in the moral luck literature (Browne 1992, p. 348 f.; Enoch 2012; Sussman 2018; Williams 1981, p. 28 f.; Wolf 2001, p. 13). Even if an agent is completely faultless and stands causally in a certain relation to some harm or evil that occurred beyond her control, we expect different emotions from her than from bystanders: "complete indifference [...] would show a lack of sensitivity." (Browne 1992, p. 349) Moral assessments comprise of such emotional responses for things beyond control, hence the standard formulation of the control principle, which ties moral assessment to control, is too wide. Therefore, I suggest to reformulate the control principle and confine it to blameworthiness (Zimmerman 2015, p. 137). The refined formulation of the control principle can be stated as follows:

\section{$\mathrm{CP}_{\mathrm{B}}$ : People are blameworthy only for things within their control. ${ }^{2}$}

It is worth noting that blameworthiness in this formulation is yet ambiguous about its relation to blame. Some authors in the moral luck debate suggest that blame entails

\footnotetext{
${ }^{2}$ Clearly, this formulation cannot be considered a full-fledged theory of blameworthiness: The principle is still grossly oversimplified. After all, one can be blameworthy only for things that are in some way or another bad, and not all things that are in peoples' control have such negative quality: No one is blameworthy for wanting to play a game of cards. Aside from the control condition, there is also a likely demand for an epistemic condition. It should be emphasized though that the demand to incorporate these aspects, have to be addressed to both the luck-free account and the luck-sensitive account of blameworthiness that are contrasted in this paper. Thus, this is not a unique shortcoming of $\mathrm{CP}_{\mathrm{B}}$ as stated here.
} 
blameworthiness (see e.g. (Jensen 1984, p. 325): "My account begins with the claim that the moral blameworthiness of an agent is a necessary condition for the use of blaming expressions which subject that agent to overt blame.") and (Hartman 2017, p. 34): "to target someone with blame involves [...] the believe that someone is blameworthy."). This does not mean that blameworthiness entails blame: If an action is morally reprehensible, but only in a minor way, the offender is blameworthy. Yet, it might be unreasonable to blame her, because the nuisance was minor and responding to minor nuisances might cause more harm than good (Smith 2007, p. 480). Blaming as a practice of responding to blameworthiness simpliciter should attune to moral reasons. Blameworthiness simpliciter is not the only condition that is relevant to determine the right kind and degree of blame. Consider excuses: You might be blameworthy for not rescuing a child, but if you had had to sacrifice your own child for its rescue, you are excused (Fischer and Tognazzini 2011, p. 388 f.). You are blameworthy but free of blame. The control principle according to my understanding applies to blameworthiness simpliciter. In contrast to the practical questions of blame, the questions regarding someone's blameworthiness simpliciter are "verdictive" (Jensen 1984, p. 329 f.) or "cognitive" (Coates and Tognazzini 2012, p. 199). As in other contexts, where verdictive judgments are made, epistemic reasons including certain methodological norms play a role. Hence, judgments of people's blameworthiness simpliciter ought to follow methodological norms such as, for example, simplicity. This is particularly important as most people desire to be judged rightly, even if they need not expect any repercussions in terms of blame. As CP has been under attack, I will outline this in more detail in the following section.

\section{Simplicity}

As outlined before, $\mathrm{CP}$ is usually defended with reference to intuition and fairness only. If fairness were to be rejected on good grounds, then CP is disarmed. Whether fairness can be rejected on good grounds shall not be discussed here. Instead, I want to propose a different defence of CP. This defence of CP hinges on the methodological value of simplicity. In a nutshell, the argument goes like this: 1) Simplicity is an important methodological guiding principle for theory choice. Simplicity suggests that, if a theory $\mathrm{T}$ is simpler than $\mathrm{T}^{*}$ (all other things being equal), then it is reasonable to prefer T over $T^{*} .2$ ) The control principle $\left(\mathrm{CP}_{\mathrm{B}}\right)$ is simpler than other theories of blameworthiness (e.g. those accepting luck). Hence, 3 ) it is reasonable to adopt the control principle instead of adhering to other accounts of blameworthiness (e.g. those accepting luck). Neither of the two premises is uncontroversial. Let us, therefore, discuss each of them in turn.

Many philosophers have argued for simplicity as an important aesthetic and scientific value (Baker 2016; Sober 2015; Swinburne 1997). One of the reasons most often cited for the value of simplicity is that simpler theories are more likely to be true than complex ones. ${ }^{3}$ Swinburn writes, for instance: "[...] the simplest hypothesis proposed as an explanation of

\footnotetext{
${ }^{3}$ This view does not commit one to the assumption that simplicity is sufficient, or the only relevant guiding principle for theory selection. A comprehensive debate of simplicity is provided by Sober (2015), who writes in agreement with Kuhn: "[...] simplicity matters in theory evaluation, but there is no 'algorithm' that tells you how much it matters compared with others relevant considerations." (p. 148)
} 
phenomena is more likely to be the true one than is any other available hypothesis, that its predictions are more likely to be true than are those of any other available hypothesis [...]." (Swinburne 1997, pp. 1, 24; Sober 2015, pp. 148-152).

Like other authors, I understand simplicity here as a guiding norm for theory choice: "If $T$ is simpler than $T^{*}$ then it is rational to adopt $T$ as one's working theory [...]." (Baker 2016) When talking about simplicity regarding theories of blameworthiness, we are not referring to ontological simplicity viz. parsimony, but rather about elegance as an epistemic value (see for this distinction (Baker 2016)). Elegance means the slenderness of a formulation, a theory or a principle. Swinburn connects elegance and syntactic simplicity as follows: "One theory is simpler than another if and only if the simplest formulation of the former is simpler than the simplest formulation of the latter." (Swinburne 1997, p. 23) If a theory of blameworthiness is simpler than its strongest competitor, it is more likely to be true and, thus, it is reasonable to accept it.

Usually, the concept of simplicity so understood is guiding theory choice in science, which has been fruitfully applied in the context of evolutionary biology (Sober 2015). One might object at this point: Granted that simplicity increases the likelihood of a theory to be true, it might be an important consideration for theory choice in science. But, why does likelihood of truth matter in the context of blameworthiness? Scientific theories have features, which theories of blameworthiness lack: Scientific theories are used to explain natural events such as planetary motions and they help to predict some of these. Theories of blameworthiness fulfil neither of those functions: They neither explain evil human behaviour nor do they help to predict it. This, however, does not imply that theories of blameworthiness cannot yield wrong judgments: Whatever kind of property "blameworthiness" is, judgements about blameworthiness are truth-apt (Coates and Tognazzini 2012; Jensen 1984). When we judge a person blameworthy, who was drugged or hypnotized and, thus, not in control of her actions, we misjudge her. When we judge someone blameworthy based on misinformation, we misjudge her. Hence, truth-aptness appertains to theories of blameworthiness. At this point, we are still in search for an argument in support of choosing a theory that is more likely to be true than its more complex competitors.

There are three candidates for such argument. First, one could suggest that it is reasonable to adopt a theory of blameworthiness more likely to be true, because truth is intrinsically good. But truth's intrinsic goodness is contested (Christensen 2013; Wrenn 2017), therefore, I am reluctant to rely on truth's intrinsic goodness for my argument. The second argument suggests that blameworthiness and blame, while being conceptually distinct, should not be practically disconnected: Blaming people that are not blameworthy or blaming people that are blameworthy to a minor degree very harshly is unfair (Enoch and Marmor 2007, p. 433; Hieronymi 2004). While it is not unfair to judge a drugged person for a certain action blameworthy - it is simply wrong - we usually translate those judgments into blaming practices. If those blaming practices are based on misjudgements, they result in unfair blame. The drugged person will unfairly receive more blame than she deserves. While this line of reasoning is appealing, it makes my argument dependent on a justification of fairness and fairness has also been contested in the moral luck debate (Hanna 2014; Hartman 2019b). Therefore, I am favouring a third argument. It is a common desire not to be judged wrongly, even if no blaming consequences are to be expected. People desire being judged in concurrence with their real moral status and they disregard being morally misrepresented. Consider 
the following example: On vacation you meet a couple at your hotel with whom you spend nice evenings and have interesting conversations. Short before the couple departs, a gust of wind blows their clothes from the drying rack all over the hotel garden. The gardener, who despises you, tells them that it has been you, who produced this mess in a rage attack. Resentful, the couple collects their dirty clothes and departs. You have no chance to straighten the record and you will never see them again. Clearly, you will resent the gardener for spreading lies about you. But, even after he apologizes, the certainty that the couple thinks bad of you leaves a bitter aftertaste and if you could, you would contact them to explain the misunderstanding.

It is plausible that most people find it unpleasant and desire to avoid that - as in the described case - others think badly about them. This desire makes reasonable to prefer theories of blameworthiness that are more likely true than others, and this appertains to simpler theories.

This brings us to premise 2). Having elaborated a formulation of $\mathrm{CP}_{\mathrm{B}}$ in Section 2, we have to ask, whether $\mathrm{CP}_{\mathrm{B}}$ is indeed simpler than other theories of blameworthiness. In order to address this question, we shall compare $\mathrm{CP}_{\mathrm{B}}$ to its rivals proposed by moral luck defenders. What are the accounts of blameworthiness proposed by defenders of moral luck? While defenders of moral luck suggest that CP isn't a creditable theory of blameworthiness, they often miss to provide a positive theory of blameworthiness of their own. Hanna admits this right away (2014, p. 693). The negation of $\mathrm{CP}_{\mathrm{B}}$ says that it is not the case that people are blameworthy only for things within their control. Can defenders of moral luck simply endorse the negation of $\mathrm{CP}_{\mathrm{B}}$ and thereby put the case at rest? Clearly, they are not forced to adopt a positive theory of blameworthiness. However, this would be a major neglect: It is commonly assumed that the primary task of a theory of blameworthiness viz. responsibility is to "specify the appropriate relationship one must stand to such things [e.g. the death of a victim] in order to be morally responsible for them" (Khoury 2018, p. $1358 \mathrm{f}$.), which the negated version of $\mathrm{CP}_{\mathrm{B}}$ omits. The moral luck debate commences considering unsettling cases such as the drunken driver that demand to be debunked or otherwise appropriately responded to. The assertion that it is not the case that one is blameworthy only for things within one's control is of no help in judging the blameworthiness of the agents in such cases. To be fair, it is easy to imagine tricky examples to which $\mathrm{CP}_{\mathrm{B}}$ cannot provide a definite judgment either. What exactly is within human control is still debatable and whether someone is, for instance, in control of a certain habit is hardly determinable from an external point of view (McKinnon 2013; Khoury 2018). In contrast to its simple negation, however, $\mathrm{CP}_{\mathrm{B}}$ offers at least a standard according to which one could in principle make such judgment, if one were fully informed.

Another way to accommodate luck in a theory of blameworthiness - which would also be extremely simple - is by reversing the control principle. Defenders of moral luck could propose $\mathrm{CP}_{\mathrm{R}}$ : People are responsible for things beyond their control.

But, $\mathrm{CP}_{\mathrm{R}}$ is clearly no acceptable theory of blameworthiness: First, even defenders of moral luck will agree that the formulation is too extensive. Being blameworthy for anything that is beyond control, includes, for instance, the wrongs committed by other people, even those committed before the accused person was born. Judging people blameworthy for such things would be absurd. Nonetheless, these things are entailed in the reversed control principle. If people can be blameworthy for things beyond control, then they can be blameworthy for such things, which is absurd. Second, even a 
narrower formulation will have to accommodate the fact that defenders of moral luck think that the unlucky drunken driver is more blameworthy than the lucky one (Hartman 2017, p. 10; 2019, p. 228). Defenders of moral luck suggest that there is unequal blameworthiness due to luck, but the revised control principle cannot explain this difference: Whether someone stands on the street is equally beyond their control, hence they would be equally blameworthy. Like the original control principle, the reversed control principle is equalizing. This feature is endorsed by deniers of moral luck but rejected by its defenders such as Robert Hartman. This line of thought corroborates the argument stated before: Defenders of moral luck will have to explain, why the drunken driver is more blameworthy. An explanation for this is not entailed in the negated control principle, which only says that it is not the case that people are blameworthy only for things within their control.

Again, defenders of moral luck need a positive account that enumerates, which things beyond control people are blameworthy for. Only then will they have a systematic account that captures the difference in blameworthiness between the drunken drivers, on which defenders of moral luck insist. Defenders of moral luck are required to provide an account of blameworthiness that is not as wide as the revised control principle, not as narrow as the control principle, and that supports their claim that things beyond control make a difference in blameworthiness.

Hartman suggests the following:

The idea [of the Moral Luck View (MLV)] is that the way in which luck affects an agent's voluntary actions and the consequences that she foresees or could reasonably be expected to foresee can partially determine her praiseworthiness and blameworthiness. On this view, [the unlucky driver] is more blameworthy than [the lucky one] in virtue of her deadly token consequence. (Hartman 2017, p. 10)

This conception invokes a number of remarks: First, what suggests the difference between the lucky and the unlucky driver cannot plainly be the foreseeable consequences of their actions, but those that actually occur. The foreseeable consequences are for both drivers the same and, thus, cannot explain why one ought to judge them differently: Hence, one might suggest that a theory of blameworthiness that defenders of moral luck could endorse says:

$\mathrm{MLV}_{1}$ : People are blameworthy for the foreseeable consequences of their actions that actually occur.

Since the actual consequences of the unlucky driver are different from those of the lucky one, they are unequally blameworthy. Here $\mathrm{MLV}_{1}$ fares better than the revised control principle that simply says that people are blameworthy for things beyond control. But this calls our attention to a second challenge for $\mathrm{MLV}_{1}$ : There are many reasonably foreseeable consequences, which are usually not considered sufficient for blameworthiness. Stauffenberg foresaw that the Second World War would continue and cost thousands of more lives, if Hitler would not be stopped. He was motivated to assassinate Hitler to prevent exactly this from happening. But Stauffenberg failed. As a consequence of his failure - a failure due to luck - the war did not end. Stauffenberg's 
failure to kill Hitler led to the continuation of the war, which continued - foreseeably to cost lives and, thus, Stauffenberg is blameworthy for these deaths. This seems wrong, and unlike MLV, the control principle captures aptly why: Stauffenberg is not blameworthy for the crimes Hitler committed after he tried to assassinate him (and many of those he committed before), because Hitler's actions were beyond his control. Foreseeable consequences of our actions often include things that other people do, if we fail to prevent them. Usually, this is not what we are blameworthy for. Hence, MLV has to be refined to deal satisfactorily with this and similar examples. Maybe some form of control does matter to defenders of moral luck after all, or they will have to explicitly exclude the reasonably foreseeable actual consequences of other people's actions from their theory of blameworthiness, which means that MLV gets more complex.

Even if those worries are compellingly addressed, it is clear the $\mathrm{MLV}_{1}$ cannot satisfy the ambitions of defenders of moral luck, which is another reminder of the comparative task at hand: Hartman, like others defenders of moral luck, does not only accept resultant moral luck, but also circumstantial and constitutive moral luck (Hartman 2017, p. 10: 2019, p. 228). But, $\mathrm{MLV}_{1}$ does not cover these forms of luck: What is needed is an account that also considers the alleged differences in blameworthiness between people, who faced circumstantial and constitutive luck. Consider Judge Actual and Judge Counterfactual: Both judges would willingly accept a bribe, but only Actual gets one offered and accepts it. According to moral luck defenders, Judge Actual is more blameworthy. Different circumstances provided the judges with different opportunities, and those circumstances account for the different actions they actualize. Their moral blameworthiness hinges on the execution of different actions and not on the consequences, which are captured by $\mathrm{MLV}_{1}$ (although the consequences of Actual's actions will likely be different than Counterfactual's). Hence, defenders might propose:

$\mathrm{MLV}_{2}$ : People are blameworthy for reasonably foreseeable consequences that actually occur and for what they actually do.

Still, the differences in constitutive luck are insufficiently captured. According to Hartman, constitutive luck “occurs when an agent's dispositions or capacities are not voluntarily acquired and they affect her positive praiseworthiness or blameworthiness for a trait or an action." (Hartman 2019a, p. 228). The following third iteration of MLV incorporates this idea:

$\mathrm{MLV}_{3}$ : People are blameworthy for reasonably foreseeable consequences that actually occur, for what they actually do and for the kind of traits they actually possess.

Whether $\mathrm{MLV}_{3}$ is an acceptable proposal for a theory of blameworthiness for defenders of moral luck is of minor importance here. We saw MLV growing in length and complexity with each iteration. $\mathrm{MLV}_{3}$ 's complexity and length are a product of the need to shield people from being judged blameworthy for everything beyond their control. The lengthiness also emerges from defenders' insistence on the unequal blameworthiness of lucky and unlucky people due to different factors including consequences, constitutive and circumstantial factors. In direct contrast to $\mathrm{MVL}_{3}$, we 
can now recall $\mathrm{CP}_{\mathrm{B}}$ once more and clearly discern its simplicity: People are blameworthy only for things within their control.

Nathan Hanna, who defends circumstantial moral luck, says that he is inclined to think "that circumstantial luck, constitutive luck, and resultant luck stand or fall together." (p. 695) Hanna might have recognized that a theory as simple as $\mathrm{CP}_{\mathrm{R}}$, which considers people to be blameworthy for anything, is absurd, as he emphasizes that he doesn't want to dismiss control altogether. He writes that "none of [these arguments against $\mathrm{CP}_{\mathrm{C}}$ ] show that control is irrelevant for moral responsibility." But Hanna admits that he doesn't know how relevant control is (p. 693). It seems that he would advocate a multifactor account of moral responsibility, very much alike $\mathrm{MLV}_{3}$ as suggested before. He says that control plays a role for moral responsibility, together with circumstances and consequences beyond control: "I think that our degree of responsibility and our moral standing more generally depend partly on the effect that we have on the world." (Hanna 2014, p. 695) And more generally, he notes before that "one's degree of responsibility is a function of various factors [...].” (Hanna 2014, p. 693 f.)

Such a multifactor account of responsibility viz. blameworthiness probably resembles $\mathrm{MLV}_{3}$. In light of my previous argumentation, it should be clear that $\mathrm{CP}_{\mathrm{B}}$ has an advantage over $\mathrm{MLV}_{3}$ : It is much simpler. Simplicity as a guiding norm advices $\mathrm{CP}_{\mathrm{B}}$ over $\mathrm{MLV}_{3}$ as a theory of blameworthiness. If we put - for the sake of argument - other arguments for and against moral luck aside, and assume that the debate has reached a stalemate between conflicting intuitions regarding the acceptability of the control principle, then the argument brought forward here puts deniers of moral luck and their core commitment to the control principle in an advanced position.

\section{Conclusions}

I have argued that the control principle shall be confined to blameworthiness, because responsibility and moral assessment encompass things beyond control. Unlike questions regarding blame, questions about blameworthiness are purely verdictive. Thus, theories of blameworthiness should be chosen based on relevant guiding norms. As the control principle has often been relied upon purely based on intuitions, it came under attack for being poorly defended. I tackled this shortcoming by arguing that the control principle is a theory of blameworthiness that is simpler than other theories of blameworthiness. Simpler theories are more likely to be true. Theories of blameworthiness that are more likely to be true are favourable, because most people desire not being falsely judged blameworthy. I then showed that the control principle is simpler than theories of blameworthiness that accept luck. Defenders of moral luck cannot simply reverse the control principle: It would be absurd to judge people blameworthy for anything beyond their control. This gives rise to the demand to positively enumerate the factors beyond control that make a difference for blameworthiness. As a result, defenders of moral luck will arrive at a theory of blameworthiness more complex than $\mathrm{CP}_{\mathrm{B}}$. If the debate about moral luck were a stalemate about intuitions, then the arguments brought forward here would put deniers of moral luck and their core commitment to $\mathrm{CP}$ in a much better position. 
Acknowledgements I am indebted to Michael Klenk, Daniel Frank, David Ludwig and Ibo van de Poel, who made several valuable suggestions to improve this paper.

Funding Information This paper has been funded by the European Union's Horizon 2020 research and innovation programme under the Marie Skłodowska-Curie grant agreement No 707404.

Open Access This article is licensed under a Creative Commons Attribution 4.0 International License, which permits use, sharing, adaptation, distribution and reproduction in any medium or format, as long as you give appropriate credit to the original author(s) and the source, provide a link to the Creative Commons licence, and indicate if changes were made. The images or other third party material in this article are included in the article's Creative Commons licence, unless indicated otherwise in a credit line to the material. If material is not included in the article's Creative Commons licence and your intended use is not permitted by statutory regulation or exceeds the permitted use, you will need to obtain permission directly from the copyright holder. To view a copy of this licence, visit http://creativecommons.org/licenses/by/4.0/.

\section{References}

Anderson, M. B. (2019). Moral luck as moral lack of control. The Southern Journal of Philosophy, 57(1), 529. https://doi.org/10.1111/sjp.12317.

Baker, A. (2016). Simplicity. In E. N. Zalta (Ed.), The Stanford Encyclopedia of Philosophy (Winter 2016 ed.). Metaphysics Research Lab, Stanford University.

Browne, B. (1992). A solution to the problem of moral luck. The Philosophical Quarterly, 42(168), 345-356. https://doi.org/10.2307/2219685.

Christensen, R. (2013). Is truth valuable? Philosophy, 88(3), 451-466.

Coates, D. J., \& Tognazzini, N. A. (2012). The nature and ethics of blame. Philosophy Compass, 7(3), 197207. https://doi.org/10.1111/j.1747-9991.2012.00477.x.

Enoch, D. (2012). Being responsible, taking responsibility, and penumbral agency. In U. Heuer \& G. Lang (Eds.), Luck, value, and commitment - themes from the ethics of Bernard Williams (pp. 95-132). Oxford: Oxford University Press.

Enoch, D. (2019). Playing the hand you're dealt: How moral luck is different from morally significant plain luck (and probably doesn't exist). Midwest Studies in Philosophy, 43(1), 257-270. https://doi.org/10.1111 /misp. 12115.

Enoch, D., \& Marmor, A. (2007). The case against moral luck. Law and Philosophy, 26(4), 405-436. https://doi.org/10.1007/s10982-006-9001-3.

Fischer, J. M., \& Tognazzini, N. A. (2011). The physiognomy of responsibility. Philosophy and Phenomenological Research, 82(2), 381-417. https://doi.org/10.1111/j.1933-1592.2010.00458.x.

Hanna, N. (2014). Moral luck defended. Nô̂s, 48(4), 683-698. https://doi.org/10.1111/j.14680068.2012.00869.x.

Hartman, R. J. (2016). Against luck-free moral responsibility. Philosophical Studies, 173(10), 2845-2865. https://doi.org/10.1007/s11098-016-0640-4.

Hartman, R. J. (2017). In defense of moral luck: Why luck often affects praiseworthiness and blameworthiness. New York: Routledge.

Hartman, R. J. (2019a). Accepting moral luck. In I. M. Church \& R. J. Hartman (Eds.), The Routledge handbook of the philosophy and psychology of luck (p. 227). New York: Routledge.

Hartman, R. J. (2019b). Moral luck and the unfairness of morality. Philosophical Studies, 176(12), 31793197. https://doi.org/10.1007/s11098-018-1169-5.

Hieronymi, P. (2004). The force and fairness of blame. Philosophical Perspectives, 18(1), 115-148. https://doi.org/10.1111/j.1520-8583.2004.00023.x.

Jensen, H. (1984). Morality and luck. Philosophy, 59(229), 323-330. https://doi.org/10.1017 /s0031819100069916.

Khoury, A. C. (2018). The objects of moral responsibility. Philosophical Studies, 175(6), 1357-1381. https://doi.org/10.1007/s11098-017-0914-5.

McKinnon, R. (2013). Getting luck properly under control. Metaphilosophy, 44(4), 496-511. https://doi. org/10.1111/meta.12044.

Nagel, T. (1991). Moral luck. InMortal questions (pp. 24-38). London: Cambridge University Press. 
Nelkin, D. K. (2013). Moral luck. In E. N. Zalta (Ed.), The Stanford encyclopedia of philosophy (Winter 2013 ed.). Metaphysics Research Lab, Stanford University. https://plato.stanford.edu/archives/win2013 /entries/moral-luck/.

Smith, A. M. (2007). On being responsible and holding responsible. The Journal of Ethics, 11(4), 465-484. https://doi.org/10.1007/s10892-005-7989-5.

Sober, E. (2015). Ockham's razor - A user's manual. Cambridge: Cambridge University Press.

Sussman, D. (2018). Is agent-regret rational? Ethics, 128(4), 788-808. https://doi.org/10.1086/697492.

Swinburne, R. (1997). Simplicity as evidence of truth. Milwaukee: Marquette University Press.

Williams, B. (1981). Moral luck. InMoral luck (pp. 20-39). Cambridge: Cambridge University Press.

Wolf, S. (2001). The moral of moral luck. Philosophical Exchange, 31(1), 1-19.

Wrenn, C. B. (2017). Truth is not (very) intrinsically valuable. Pacific Philosophical Quarterly, 98(1), 108128.

Zimmerman, M. J. (2006). Moral luck: A partial map. Canadian Journal of Philosophy, 36(4), 585-608. https://doi.org/10.1353/cjp.2007.0006.

Zimmerman, M. J. (2015). Moral luck reexamined. In D. W. Shoemaker (Ed.), Agency and responsibility (Vol. 3, pp. 136-159). Oxford: Oxford University Press.

Zimmerman, M. J. (2019). Denying moral luck. In I. M. Church \& R. J. Hartman (Eds.), The Routledge handbook of the philosophy and psychology of luck (pp. 216-226). New Jersey: Routledge.

Publisher's Note Springer Nature remains neutral with regard to jurisdictional claims in published maps and institutional affiliations. 